\title{
自己強化の新反応形成機能の発達的研究
}

\author{
広島大学 ${ }^{1}$ 平川忠 敏 ${ }^{2}$

\section{A DEVELOPMENTAL STUDY OF THE FORMATION OF NEW RESPONSES BY SELF-REINFORCEMENT}

TADATOSHI HIRAKAWA

\author{
Department of Child Psychology, Hiroshima University
}

\begin{abstract}
To examine the formation of new responses by self-reinforcement (SR), 48 preschoolers (five-year-olds) and 48 third graders (eight-year-olds) were asked to choose one of the four geometric figures, under the conditions of verbal self-reinforcement (V-SR), material self-reinforcement (M-SR), or non self-reinforcement (N-SR). A measure taken was the rate of successive choices of the same figures self-reinforced over the trials. Both V-SR group and M-SR group performed significantly better than $\mathrm{N}$-SR group, but no increment was found over trials. It seemed that V-SR was functionally equivalent to M-SR in five-year-olds, while V-SR was more dominant than M-SR in eight-year-olds. The number of SR made by five-year-olds in both V-SR group and M-SR group was more than that of eight-year-olds.
\end{abstract}

Skinner (1953) によれば, 自己コントロールは社会 的学習の産物であり, 自己コントロールの学習と維持に はたらいているものは自己強化（以下 SR と略す）であ るとした. その後 Kanfer, Bradley, \& Marston (1962), Marston \& Kanfer (1963), 柏木 (1972) は直接学習の 立場から，Bandura \& Kuper (1954) は観察学習の立場 からそれぞれ SR とついて研究している.

しかしどちらの研究もともに SR の導入に視点が置か れ，SR の持つ機能については十分な検討がなされてい ない（春木，1975). Bandura (1971） る指摘しているよ らに，代理性強化や SR といったいわゆる“ハイフンつ きの強化”は，一般学習事態に括ける “強化”之同様の 機能を持っているか否かといった問題が生じてくる.

Montgomery \& Parton (1970) は, SRされた反応は 漸増的傾向を示し, SR が新反応形成機能を持つことを 見出している. 彼らの研究はSR の方法としてレバー押 し反応をする群とレバーを押すと貨幣が与えられる群 の 2 群を設定している. 一般に貨幣を他人からもらうこ とはあってる自分自身炕党ることはないと言ってよか ろう。同様に，従来から行われているチップなどを SR として取る際も，他者がしつらえた物を取るやり方であ

1 現所属 鹿児島大学教養部.

2 本研究に対して終始暖かいご指導を戴いた広島大学 教育学部幼児心理学教室の祐宗省三助教授飞厚く招礼申 しあげます。また実験に心よくご協力下さいました広島 市立祇園小学校の教師・児童の皆様特よび宇品学園の保 母・園児の皆様に厚くお礼申しまげます.
る. 確かにこのような貨幣やチップを取るやり方で $\mathrm{SR}$ の新反応形成に関する研究を行うことも可能であるが, SR の特質をより厳密にとらえるやり方の 1 つとしては 被験者自身が言語化による自己強化(以下 V-SR と略す) を行うことが考兄られる。皇こで本研究は，従来行われ てきた物質を取る自己強化（以下 M-SR と略す）と VSR を設定して，それらが SR の新反応形成機能に及注 す効果を検討するものである，また M-SR と V-SRを発 達的に検討することによって，外的強化と同様に SR も 1 次的強化から 2 次的強化へと発達するものか否かとい った発達と SR の関係も検討できよう。

一般に年少児では，言語による行動統制力の水準が年 長児よりる低いといわれるが，これはV-SRが十分に確 立していないことと一致していると考兄らる。他方， 年長児では言語による行動統制力が年少児より発達して いるのでV-SRが十分に確立していると考光られる。 た，年長児は年少児よりもフィードバック機能や自己強 化規準などが十分に確立していると思われるので新反応 形成率は年長児の方が大きいであろう，以上のことから 次の仮説を立てた.

仮説 $1 \mathrm{SR}$ は新反応形成機能を示すが，年少児 ( 5 歳児）では M-SR が V-SRより SR 回数も新反応形成率 も大きいであろう。

仮説 2 年長児（8歳児）では, V-SR がM-SR 上り SR 回数も新反応形成率も大きいである

仮説 3 発達的にみると年長児は年少児に比べて新反 応形成率が大きいであるう。 
方 法

被験者 被験者はこの種の実験飞未経験な広島市内の 保育園児 48 名（男女各 24 名）, 小学 3 年生 48 名（男 女各 24名) であった.

材料 文化無影響知能テスト ${ }^{3}$ から抽出した各図形を $6.5 \mathrm{~cm} \times 6.5 \mathrm{~cm}$ の正方形の枠の中描き, 互いに類似 した図形 4 個を 1 組として $27.5 \mathrm{~cm} \times 19.5 \mathrm{~cm}$ の白色台 紙に貼りつけた。このようにして作製された一貫性のな いそれぞれ異なる刺激カード 10 枚が 8 歳児用として, 5 枚が 5 歳児用として用いられた。Fig. 1 はその 1 例で ある。

実験計画 被験者は 5 歳児, 8 歳児とも气れぞれ V$\mathrm{SR}$ 群, M-SR 群, SR なし群（以下 N-SR 群と略す）の 3 群に分け, 各々飞 $2 \times 3$ の要因計画を用いた。 V-SR 群は強化子として実験者飞るよく聞こえるょうに'上く できた’という言葉を用い，M-SR 群の男子はビー玉， 女子はオ八ジキを強化子として用いた，N-SR 群は強化 子を用いず毎試行任意に図形選択だけをする群であった (Table 1 参照).

手続き 刺激カードは， 8 歳児では 10 枚を 1 ブロッ ク（5歳児では 5 枚を 1 ブロック）として同じるのが連 続 5 ブロック提示された. 提示順序和よび各四形の位置 は各ブロックごとにランダムに変えられ，刺激カードは 1 枚ずつ提示された。

実験者は被験者圭個別飞実験室へ誘導し，V-SR 群の 被験者には次の教示を与光た。“あなたは何かよいこと 定したり成績がよかった時，先生や家族の人から脑めて もらったことがあるでしょう。きょうはよくできたと思

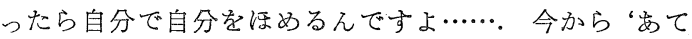
っこゲーム゙をしましょう４４枚の図形の描かれたカー ドが何回もでてきます. 4 枚の図形の中のどれか 1 枚だ

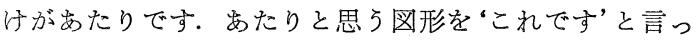
て指さして下さい。あたっている自信があったら自分で “よくできた’と言って自分をほめて下さい”。

M-SR 群の被匰者の前にはビー玉（女子はオ八ジキ） が多数入った皿が置いてあり，あたっていると思ったら 自分で 1 個取るように教示した. N-SR 群は強化子を用 意せず, 強化浪っいての教示は一切与充なかった.

前回の試行飞䄧いて被騟者が選択してSRし, 次回(次 のブロック）の試行でる連続して同一図形を選択した回

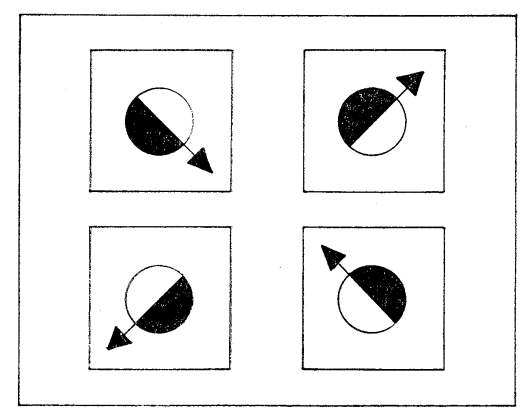

FIG. 1. An example of stimulus cards.
TABLE 1

Age of subjects

\begin{tabular}{|c|c|c|c|c|c|c|}
\hline \multirow{2}{*}{ Group } & \multicolumn{3}{|c|}{ 5-year-old children } & \multicolumn{3}{|c|}{ 8-year-old children } \\
\hline & $N$ & $\bar{X}$ & Range & $N$ & $\bar{X}$ & Range \\
\hline $\mathrm{V}$ & $\begin{array}{l}\text { Boy : } 8 \\
\text { Girl : } 8\end{array}$ & $5: 02$ & $\begin{array}{l}4: 05 \\
-6: 01\end{array}$ & $\begin{array}{l}\text { Boy : } 8 \\
\text { Girl }: 8\end{array}$ & $8: 10$ & $\begin{array}{l}8: 01 \\
-9: 01\end{array}$ \\
\hline M & $\begin{array}{l}\text { Boy : } 8 \\
\text { Girl }: 8\end{array}$ & $5: 02$ & $\begin{array}{l}4: 06 \\
-6: 02\end{array}$ & $\begin{array}{l}\text { Boy : } 8 \\
\text { Girl : } 8\end{array}$ & $8: 07$ & $\begin{array}{l}8: 03 \\
-9: 01\end{array}$ \\
\hline $\mathrm{N}$ & $\begin{array}{l}\text { Boy : } 8 \\
\text { Girl : } 8\end{array}$ & $5: 01$ & $\begin{array}{l}4: 05 \\
-6: 02\end{array}$ & $\begin{array}{l}\text { Boy }: 8 \\
\text { Girl }: 8\end{array}$ & $8: 08$ & $\begin{array}{l}8: 04 \\
-9: 02\end{array}$ \\
\hline
\end{tabular}

Notes. $\mathrm{V}$ is verbal sel-reinforcement group. $\mathrm{M}$ is material self-reinforcement group. $\mathrm{N}$ is control group (non self-reinforcement group).

数（率）が測度とされた。例觉ば 8 歳児の場合，第 1 ブ ロック 10 試行中, 6 試行の選択反応飞対し SR したと する，元の SR した図形を次の第 2 ブロックに和いてす べて選択したら同一図形連続選択率は 100\%で岕り，3 個の図形を選択したら $50 \%$ となる。

\section{結 果}

（1） 同一図形連続選択率(新反応形成率） 全反応は 5 ブロックから成って拉り, 前回（前ブロック）選択し SR した図形を，次回（次のブロック）も選択したか否 かをどのブロックについてる算出した。すすおわ， I II $, \mathbb{I I}-\mathrm{III}, \mathbb{I I}-\mathrm{N}, \mathrm{N}-\mathrm{V}$ のブロックにおいて前回 SR し た総数の中で次回も同一図形を選択した割合を示したの が Fig. 2 と Fig. 3 である.

8 歳児の V-SR 群の II-IIIブロックが， I- IIブロック より増加している傾向がみられたが $(t=1.98, d f=30$, $.05<p<.10)$, 他の群では 5 歳児, 8 歳児とも安定した 選択率を示した。

Table 2 は全ブロックをこみにして各群ごとにまとめ たものである. 5 歳児の V-SR 群と M-SR 群の間には有 意差がないが，V-SR 群も M-SR 群もともに N-SR 群よ り有意に多い同一図形連続選択率を示している（V-SR 群と N-SR 群, $t=2.94, d f=126, p<.01 ; \mathrm{M}-\mathrm{SR}$ 群と N-SR 群, $t=2.98, d f=126, p<.01) .8$ 歳児では, M-SR 群が N-SR 群より多い傾向を示したが $(t=1.82$, $d f=126, .05<p<.10), \mathrm{V}-\mathrm{SR}$ 群と M-SR 群及び V-SR 群と N-SR 群には有意差がみられなかった．発達的にみ ると，N-SR 群に和いて8 歳児が有意に多い選択率を示 した $(t=2.67, d f=126, p<.01)$.

(2) 自己強化回数の割合 5 歳児では 1 ブロック 5 試行, 8 歳児では 10 試行中に SR した割合が Fig. 4 と Fig. 5 に示されている. 5 歳児は V-SR も M-SR も各ブ ロック約 80\%の のR を行って特り,ブロック間に有意

3 R.B. キャッテル・A.K.S. キャッテル・大脇義一・ 栗林宇一 文化無影響知能テスト $(2 \mathrm{~A})$ 三京房 
差はみられなかった。 8 歳児の V-SR では第Iブロック がIII， N，Vのブロックより少ない傾向にあった（Ｉ－III，

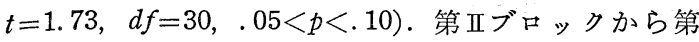
Vブロックまでの変動には有意差はなかった。 また MSR は約 60\% で安定して和り，ブロック間の変動に有 意差はみられなかった。

Table 3 は各群ごとに全ブロックをまとめたものであ る. 5 歳児の V-SR 群と M-SR 群には SR 回数の割合に 有意差がないが，8歳児ではV-SR 群が M-SR 群より有 意に多い $(t=3.64, d f=158, p<.001)$. 発達的にみる そ, V-SR 群では 5 歳児が有意に多く $(t=3.04, d f=$ $158, p<.005), \mathrm{M}-\mathrm{SR}$ 群では 5 歳览が有意に多く強化 している $(t=6.93, d f=158, p<.001)$.

考 察

本研究では Fig. 2 と Fig. 3 から明らかなように 5 歳児 も 8 歳児も漸増的傾向を示していない，わずかに 8 歳児 の V-SR 群に和いてII-IIIブロックで増加している傾向 がみられるが次のブロックからはまた I-II ブロックの 水準に低下し安定している. N-SR 群との比較に和いて は，8歳児のV-SR 群を除きどの群も N-SR 群より有意 に多いかあるいは多い傾向がみられる，従って，本研究 では SR が強化機能を持っていることは実証されたが， 新反応を形成する機能を持っているとはいえず，仮説 1 の前半は 5 歳児， 8 歳児ともに支持されなかった。 また， 8 歳児は N-SR 群でもかなりの反応生起率がみられるの で, V-SR 群や M-SR 群と N-SR 群の間に 5 歳児ほどの 明確な差異がみられなかった. SR は, 外的強化と比べ て反応手掛かりについての情報が少なく本研究のような 非ルール課題の場合はとくに情報が少なくなると考えら れる. 従って反応と強化の結びっきが弱く，このよらな 40\% 強の同一図形連続選択率しか示さなかったのであ

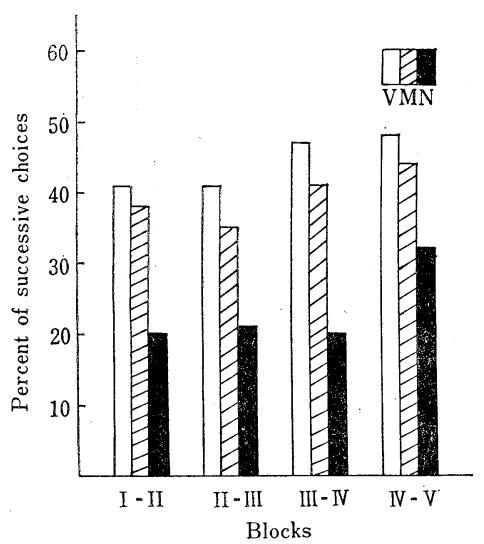

FIG. 2. Percent of successive choices of the same stimulus card over two successive blocks by five-year-old children.
TABLE 2

Rate of successive choices for each stimulus card pooled in each group $(\sqrt{X+0.5)}$

\begin{tabular}{c|cc|cc}
\hline \multirow{2}{*}{ Group } & \multicolumn{2}{|c|}{ 5-year-old children } & \multicolumn{2}{|c}{ 8-year-old children } \\
\cline { 2 - 5 } & $\bar{X}$ & $S D$ & $\bar{X}$ & $S D$ \\
\hline $\mathrm{V}$ & 5.76 & 3.43 & 5.75 & 2.53 \\
$\mathrm{M}$ & 5.63 & 2.92 & 5.95 & 2.94 \\
$\mathrm{~N}$ & 4.20 & 2.50 & 5.24 & 1.85
\end{tabular}

TABLE 3

Rate of self-reinforcement pooled in each group $(\sqrt{X+0.5})$

\begin{tabular}{c|cc|cc}
\hline \multirow{2}{*}{ Group } & \multicolumn{2}{|c|}{ 5-year-old children } & \multicolumn{2}{|c}{ 8-year-old children } \\
\cline { 2 - 5 } & $\bar{X}$ & $S D$ & $\bar{X}$ & $S D$ \\
\hline $\mathrm{V}$ & 9.15 & 1.66 & 8.33 & 1.74 \\
$\mathrm{M}$ & 9.21 & 1.28 & 7.13 & 2.37
\end{tabular}

ろう。

5 歳児の SR 回数の割合も同一戝形連続選択率もとも. に V-SR 群と M-SR 群の間に差はなく仮説 1 の後半は支 持されなかった.一般に, 発達水準の低い 5 歳児は象徵 化された言語よりも実質的な M-SR の方が SR 回数も同 一図形連続選択率も多いと予想したが両者に差はなく, すでに 5 歳児でも言語化が物質と同様の SR 機能を持っ ていることがわかり，5歳児は言語を自己強化子として 十分用いていることが見出された.

8 歳児に関しては, V-SR 回数が M-SR 回数より多い 傾向がみられ, 同一図形連続選択率については両群に差 がないのでまだ言語化による SR が新反応形成に積極的

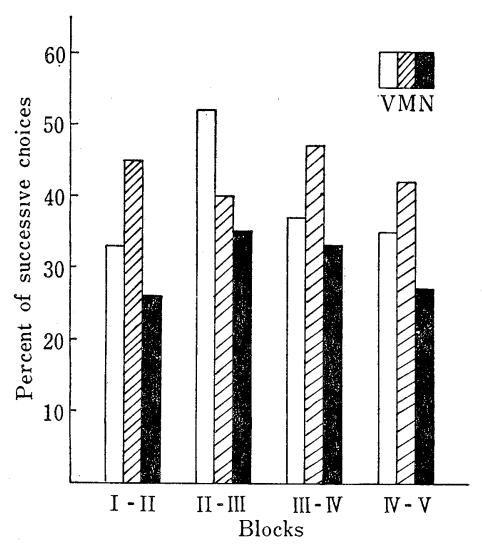

FIG. 3. Percent of successive choices of the same stimulus card over two successive blocks by eight-year-old children. 
な効果を持つにはいたらないといえる.

次に発達的にみると, 同一図形連続選択率は 5 歳巟と 8 歳児の間に差はみられなかった.このことは 8 歳児の 新反応形成率が大きいとする仮説 3 は支持されていない が， 8 歳児は 5 歳児より SR 回数が有意に少ないにもか かわらず，5歳児と同等の同一図形連続選択率を示して いることから SR の強化機能は発達とともに強くなると いえよう。また，5歳児で SR 回数が多いのはフィード バック機能や自己強化規準がまだ十分確立していないこ とから自分の反応は殆んどすべてよくできたと思ってし まうためと考元られる. また Montgomery \& Parton （1970）で新反応形成機能がみられ，本研究でみられな かったのは, 本研究の課題の方が比較的困難でありその ため被験者にとって課題意識が必ずしも十分把握されな かったためとも考觉られる。

要 約

本研究は言語化と物質を強化子として SR が新反応形 成機能を持っているか否か，ならびに SR 回数と新反応 形成水準の関係を発達的に検討した. SRをした群はNSR 群より有意に多い約 $40 \%$ の新反応の形成を示し, SR は強化機能を持っていることを示したが, 外的強化 の際に一般に示される反応の漸増的傾向はみられなかっ た.これは SR が外的強化と比べて反応手掛かりについ ての情報が少ないためと考えられる。

5 歳児ではすでに言語化が物質と同様の強化機能を示 して特り，8歳児では言語化が物質より多く強化子とし て用いられていたが，まだ言語化による SR が新反応形 成に積極的な効果を持つにはいたらないといえる。

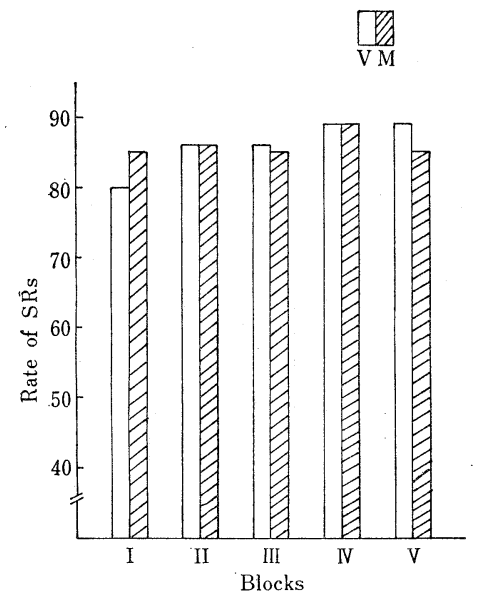

FIG. 4. Rate of SRs of each block by fiveyear-old children.
発達的にみると，言語化，物質とも5 歳児の方が 8 歳 児に比べて SR 回数が多く，新反応の形成率は差がなか った. 従って発達とともに SR 機能が強くなることがい えた。

\section{引用 文 献}

Bandura, A. 1971 Vicarious- and self-reinforcement processes. In R. Glaser (Ed.), The nature of reinforcement. New York : Academic Press. Pp. 228278.

Bandura, A., \& Kuper, C. K. 1964 Transmission of pattern of self-reinforcement through modeling. Journal of Abnormal and Social Psychology, 69, 1-9.

春木 豊 1975 人間の行動変容に打ける三つの次元 心理学評論, 18, 111-124.

Kanfer, F. H., Bradley, M. M., \& Marston, A. R. 1962 Self-reinforcement as a function of degree of learning. Psychological Reports, 10, 885-886.

柏木恵子 1972 幼児の升別学習江打ける自己強化 (selfreinforcement) の機能 心理学研究, 42, 321-327.

Marston, A. R., \& Kanfer, F.H. 1963 Human reinforcement : Experimenter and subject controlled. Journal of Experimental Psychology, 66, 91-94.

Montgomery, G. T., \& Parton, D. A. 1970 Reinforcing effect of self reward. Journal of Experimental Psychology, 84, 203-206.

Skinner, B.F. 1953 Science and Human Behavior. New York : Macmillan.

- 1976. 11. 18. 受稿一

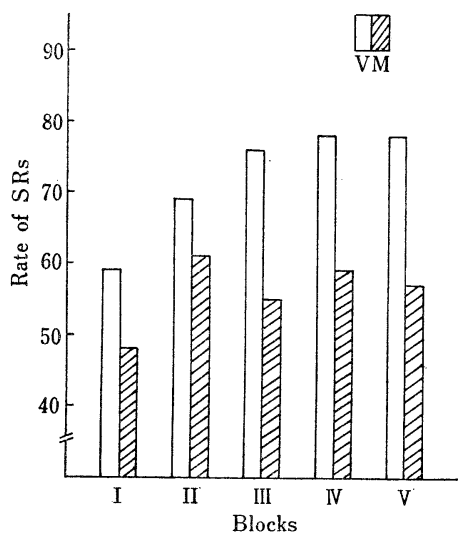

FIG. 5. Rate of SRs of each block by eightyear-old children. 